\title{
PROSPECTS FOR THE PROMOTION OF A CULTURE OF POLITICAL TOLERANCE IN LESOTHO
}

\section{Sehoai Santho}

Sehoai Santho is a governance specialist and an independent consultant with

Moruo Consulting, Maseru, Lesotho

P O Box 0752 Maseru West 105 Maseru Lesotho

e-mail: santho@telkomsa.net

\begin{abstract}
The main aim of this paper is to examine the problems and opportunities facing Lesotho in institutionalising a culture of political tolerance - an indispensable requirement in an emerging democracy. These problems and opportunities are discussed in the context of an assessment of the challenges of consolidating democratic governance in the country. Sustainable democratic governance must be based on a strong foundation of tolerance of the diverse views and perspectives of all major stakeholders, particularly political parties. This is even more relevant in the current context, where the country must manage the challenges of the post-2007 election environment.
\end{abstract}

\section{INTRODUCTION}

Lesotho's political stability has been tested frequently since the country gained independence in 1966 after 98 years as a British protectorate. In the first five years of its independence, from 1966 to 1970, the country had a democratic system of government based on a Constitution modelled on the Westminster system, with the king as head of state and the prime minister head of government.

After the first post-independence general elections, held in 1970, the then prime minister and leader of the ruling Basotho National Party (BNP), Chief Leabua Jonathan, declared a state of emergency and suspended the Constitution once it became clear that the BNP had lost the election.

This undemocratic and authoritarian order lasted until the BNP government was overthrown by a military coup in January 1986 in the context of a crippling economic blockade imposed by apartheid South Africa. The military regime lasted from 1986 to 1993, when general elections were held, marking the transition to 
the second phase of a constitutional democratic system. It was during this second phase (from 1993 to 2007/08) that the need to promote a culture of political tolerance became most urgent.

The paper raises the following questions:

- What lessons have the key role players learned from Lesotho's experience of promoting a culture of political tolerance and developing appropriate democratic governance systems?

- How should those lessons inform current practices of key role players as they address the challenges of managing Lesotho's post-2007 election dynamics?

- Are all the key role players capable of harnessing those lessons in order to establish appropriate norms, standards and institutions for sustainable democratic governance?

To answer these questions we must develop a comprehensive framework for assessing the interaction between democratic governance and development in Lesotho.

\section{THE INTERACTION BETWEEN GOVERNANCE AND DEVELOPMENT}

Among the major pillars for sustaining democracy in emerging democracies such as Lesotho is the crucial need to promote a culture of political tolerance and to inculcate democratic norms and standards that will determine the constructive conduct of key role players in a maturing democratic governance system. That process should then provide a foundation for developing effective governance systems and ensuring the attainment of inclusive, shared and pro-poor development which will benefit all citizens in the medium to long term.

There is a well-established consensus that effective governance is the fundamental basis for a successful growth and development strategy. Such a strategy should seek to ensure a dynamic interaction between the state, civil society and the markets, so that development outcomes are more pro-poor, and equity, inclusion, safety and security are assured. In the case of Africa, and, by extension, Lesotho, we can refer to two major reports that have assessed the challenges of effective governance. These are the 2005 Governance Report of the UN Economic Commission for Africa (UNECA) and the 2005 Commission for Africa Report. 
According to the UNECA document the most successful African countries are 'fairly capable democratic states with good governance that have promoted economic and human development better than African countries without these features Good governance requires a capable democratic state as well as a vigorous civil society and an innovative private sector' (UNECA 2005, p 26).

Of much more relevance to us is that the UNECA document then outlines ten priorities for building 'capable and accountable states'. Among these are: strengthening the capacity of parliaments to perform their core functions effectively, deepening legal and judicial reforms, combating corruption, fostering credible and responsible reporting by the media, improving public sector management by streamlining systems, and reducing bureaucratic inefficiency, improving the performance of civil servants through skills training and providing appropriate incentives, harnessing the skills and resources of the country's diaspora in order to counter the negative impacts of brain drain, and promoting effective decentralisation strategies to improve service delivery at local/community level.

According to the Commission for Africa 'weak governance has undermined the development of many African countries'. Weak governance encompasses: an economic and political climate which discourages both foreigners and locals from investing, excessive bureaucracy, corruption, lack of accountability, and the ineffectiveness of crucial institutions such as parliaments, the justice system, and media. The report emphasises that at the core of the governance problem is the 'lack of effective national and local governance systems'. The commission then recommends that 'African Governments should develop effective and accountable governance systems and institutions that are able to deliver to African citizens'.

The Commission for Africa also strongly endorses the New Partnership for Africa's Development (Nepad) African Peer Review Mechanism (APRM) as an African initiated governance assessment programme acceded to voluntarily by African countries. This programme seeks to identify and address 'major governance deficits' through peer driven self-assessments.

A participating country is expected to examine its governance systems comprehensively in four key areas, namely, democratic and political governance, economic governance and management, corporate governance, and socioeconomic development. Lesotho acceded to the APRM in August 2004 and is currently undergoing a peer review, the APRM schedule having been interrupted by preparations for the snap elections in February 2007.

It should, therefore, be noted that the influential reports referred to above, as well as the Nepad-APRM pan-African programme, form part of a well established regional and sub-regional consensus on the dynamic interaction between effective governance and development strategies. It is in this context 
that the promotion of a culture of political tolerance is critical among and within political parties and between other key political role players, especially during national elections. This will ensure the stability of political systems, particularly in the context of the consolidation of democratic governance.

\section{LESSONS FROM LESOTHO'S EXPERIENCE WITH THE DEMOCRATISATION PROCESS}

Lesotho has gone through various transition phases during the second wave of its democratisation, which was attributable to the combined impact of endogenous and exogenous determining factors which affected this small Southern African state with a very open economy. These phases are: the 1990-1993 period of transition from authoritarian military rule to a constitutional democracy; the 1993-1998 period, during which the emerging constitutional democracy had to manage major political stability challenges; the 1998-2002 period during which constitutional and electoral reforms were implemented in the aftermath of the 1998 elections crisis; and the 2002-2007 period of relative stability following the adoption of the mixed member proportional system (MMP). This brings us to the February 2007 election, which gave the MMP model its first major test. These four phases are discussed further below.

The 1990-1993 transition from authoritarian military rule to a constitutional democracy was initiated by a military regime in the context of internal and external pressures for democratisation. This weakened client state was also undermined by the historic changes unfolding in its patron state, South Africa, during this period. A National Constituent Assembly was established from 1990 to 1993 and ultimately produced the Lesotho Constitution (Order No 5 of 1993). The 1993 national elections were therefore held within the framework of this constitutional order.

From 1993 to 1998 this emerging constitutional democracy was faced with a variety of political stability challenges such as post-election disputes, the tense relationship between the monarchy and the emerging democratic dispensation, civil-military reform, security sector and police reform, inter-party and intra-party conflicts, and chronic political instability. This period ultimately saw a split in the ruling BCP and the emergence of the Lesotho Congress for Democracy (LCD) in 1997. The need for a culture of political tolerance has been glaring, particularly because almost all election outcomes in Lesotho's contemporary history have been bitterly disputed.

In the aftermath of the 1998 election crisis, which lasted until 2002, constitutional and electoral reforms were undertaken after the first Independent Electoral Commission (IEC)'s management of the 1998 election was bitterly disputed by the opposition parties. The electoral reform process commenced with 
an important consultative national conference in February 1999 organised by the Interim Political Authority (IPA) in collaboration with the United Nations Development Programme (UNDP). This forum involved all Lesotho's political parties and led to a consensus agreement on the need for a new electoral model in Lesotho.

The 2002-2007 period has tested the MMP electoral model, following the successful national elections of 2002 conducted by an IEC that was re-constituted in April 2000 according to a path-breaking agreement reached between the IPA and the Government of Lesotho, signed on 3 December 1999. In preparing for the 2002 elections the IEC implemented an inclusive consultative strategy that fully involved the political parties. The IEC also implemented a pro-active conflict management strategy in collaboration with civil society partners such as the Lesotho Network for Conflict Management (LNCM). ${ }^{1}$

These facilitated interventions entailed imparting constructive conflictmanagement skills and the promotion of trust-building methods to enable political parties to manage inter-party tensions and conflicts. These and other processes led to the creation of an enabling environment for holding credible and legitimate democratic elections.

Multi-faceted dialogue organised between political leaders in order to promote inter-party cooperation facilitated the successful transition from the 'firstpast-the-post' electoral system, which had contributed to the 1998 elections-related crisis, to the MMP system.

The May 2002 election was therefore universally considered to be credible, transparent, peaceful, free and fair. It resulted in the LCD becoming the ruling party as it controlled the majority in the National Assembly (the lower house of Parliament) after winning 79 of the 80 directly elected constituency seats. The 40 proportional representation (PR) seats were apportioned among the nine opposition parties which had won sufficient votes. The result was the most inclusive and representative Parliament in the history of post-colonial Lesotho.

\section{REFORMS AND INITIATIVES}

The success of the 2002 electoral process was attributed to several major reforms and innovative initiatives.

Firstly, the IPA between 1999 and 2002 served as a key platform for interparty dialogue about the electoral reform process, which ultimately led to the adoption of the inclusive MMP system.

1 Between 1999 and 2002 the LNCM was led by Sehoai Santho, who also served as lead facilitator together with a core group of facilitators of this IEC-LNCM elections conflict management programme. 
Secondly, mechanisms were introduced to ensure that all contesting parties had fair access to the state-owned media during the campaign period.

Thirdly, political parties and candidates were given the opportunity to attend regular meetings with the IEC through its various stakeholder consultative committees and to discuss and agree on how to proceed on crucial election matters.

Fourthly, organised civil society formations such as the Lesotho Council of NGOs (LCN) and the Lesotho Network for Conflict Management (LNCM) collaborated extensively with both the IPA and the IEC to implement voter and civic education and a proactive election-related conflict management programme. Finally, the LNCM implemented a UNDP-sponsored pre-election training programme on conflict transformation for the police and other security services. In this role the LNCM collaborated with other external partners such as the Centre for Conflict Resolution (CCR).

It is therefore widely agreed that these steps towards increased transparency, openness and inclusiveness resulted in the legitimacy, the credibility and the acceptability of the 2002 election outcome.

\section{THE POLITICAL CONTEXT OF THE 2007 ELECTIONS}

Intra-party and inter-party dynamics which resulted in a reconfiguration of political parties within the National Assembly precipitated the organisation of a snap election on 17 February 2007.

On 13 October 2006 a split within the ruling party, the LCD, led to the emergence of the All Basotho Convention (ABC). Following this split the 120member National Assembly was dissolved on 17 November and a national election called. This fluid and uncertain political environment affected the IEC's planning and implementation capacity and the snap election tested the resilience of Lesotho's MMP system.

The IEC once again established an effective partnership with a team of experienced facilitators who worked from 2006-2007 under the auspices of a UNDP Elections Support Project. The members of the Lesotho Elections Facilitation Team (FT) were: Sehoai Santho, team leader; Caleb Sello; and Fako Likoti. The overall goal was to facilitate the creation of an enabling environment for credible and legitimate democratic elections in accordance with Southern African Development Community (SADC) principles and universally recognised norms and standards.

The specific objectives of this project, which was titled 'Deepening Democracy in Lesotho', were inter alia, to:

- strengthen the IEC;

- support conflict transformation; 
- enhance civic responsibility;

- coordinate international support.

The FT also engaged the services of 11 election mediators trained by the LNCM in preparation for the 2002 elections. They were therefore experienced in facilitating election conflict management and mediation. Members of this core group, together with a dedicated coordinator, were given further training by the FT and the CCR in February 2007. They were then deployed successfully during the election period (13-21 February 2007) as a crucial element of the implementation of the IEC's conflict-management strategy. The facilitation process also assessed the role, composition and capacity of the IEC's Conflict Management Committee (IEC-CMC).

\section{FACILITATING POLITICAL TOLERANCE}

The election period started officially on 1 December 2006 and the facilitation process began with the FT organising a successful multistakeholder national symposium on 'Political Tolerance and Conflict Transformation' (4-5 December). The outcomes of this symposium were reached on the basis of a consensusbuilding exercise with representatives of all the political parties.

The objectives of the symposium were to:

- manage the pre-election political environment during the 90 days that remained before polling day on 17 February and the publication of election results on 26 February;

- link short-term election challenges with both medium and long-term post-election challenges;

- identify the key concerns, risks, and challenges of the pre-election period;

- develop consensus on an effective code of conduct and a political tolerance accord;

- ensure that political parties committed themselves to accepting the outcome of the election;

- ensure effective monitoring of adherence to the code of conduct and the political tolerance accord.

The intention of the FT was that political parties and other civil society participants should appreciate the crucial links between the challenges of the short-term election period and the medium- and long-term post-election challenges of consolidating democracy in Lesotho. The symposium also served to validate the scope 
of the FT's work plan, which applied to the pre-election, election, and post-election phases.

\section{IMPACT OF THE POLITICAL TOLERANCE AND CONFLICT TRANSFORMATION COMPONENT OF THE IEC-UNDP ELECTIONS PROJECT}

The original intended outcome of this component, as facilitated by the FT, was 'improved conflict management mechanisms to reduce political confrontation and antagonism while fostering political dialogue'. The target groups of this component were the national network of conflict transformation facilitators, the IEC-CMC, political parties, and civil society groups.

The overall impact of the series of facilitated political dialogue processes was the creation of an enabling environment for credible and legitimate democratic elections in accordance with SADC guidelines and universally recognised norms and standards.

Mechanisms were put in place for effective monitoring of adherence to the current code of conduct as provided for in the electoral laws. Over and above this, the facilitation team, in collaboration with the CCR, implemented a preelection conflict management training programme. This programme also enhanced the IEC's conflict management capacity by assessing and redefining the role of the IEC-CMC through the training of a core group of election-conflict mediators, who were successfully deployed under the supervision of the facilitation team in all ten districts of Lesotho during the pre-election and immediate post-election period.

\section{CONCLUSION}

The allocation of parliamentary seats after the February 2007 election was undertaken within the general framework of the MMP system, although it was questioned whether the allocation formula used by the IEC was created according to a MMP or a parallel system. This was the subject of post-election court cases at the instance of some of the opposition parties who questioned the legality and fairness of this allocation formula. The formation of pre-election party coalitions and electoral pacts are at the centre of the post-election legal disputes, which focus on the implications for the MMP model of such alliances.

This vexed issue was also one of the major areas of focus of the SADC Ministerial Troika Assessment Mission to Lesotho and the SADC-led political dialogue facilitation process (April-July 2007). 


\section{RECOMMENDATIONS}

There is a crucial need to assess the challenges and opportunities that the postelection environment presents, given the need to link Lesotho's short-term postelection challenges with democracy consolidation and development concerns in the medium to long term.

This assessment will provide a basis for outlining and facilitating the management of these governance challenges in post-election Lesotho in the context of consolidating democracy. Among the major areas of concern, the following loom large:

- Ensuring a stable post-election political environment in Lesotho and identifying the key political concerns, risks, and challenges in both the short and medium term between 2007 and 2012, with particular focus on intra-party and inter-party dynamics.

- Linking short-term post-election challenges with democracy consolidation and development concerns in the medium to long term.

- Safeguarding the principles and values of the MMP model and enhancing the effectiveness of Parliament.

- Facilitating and promoting the culture of inter-party and multistakeholder dialogue in addressing matters of national political importance.

- Assessing inter-party and intra-party dynamics, given the fact that political parties are crucial role players in the consolidation of democracy.

\section{REFERENCES}

UNECA. 2005. Striving for Good Governance in Africa: Synopsis of the 2005 African Governance Report. Addis Ababa: UNECA.

Commission for Africa. 2005. Our Common Interest: Report of the Commission for Africa, March. London: CFA Secretariat.

NEPAD-APRM. Frequently Asked Questions. NEPAD Secretariat: www.nepad.org. 